\title{
Synergetic MPPT Controller for Photovoltaic System
}

\section{Nadia Mars ${ }^{1,2 *}$, Faten Grouz ${ }^{1}$, Najib Essounbouli ${ }^{2}$ and Lassaad Sbita ${ }^{1}$}

${ }^{1}$ Research Unit of Photovoltaic, Wind and Geothermal Systems (SPEG), the National Engineering School of Gabes (ENIG), University of Gabes, Av. Omar Ibn El Khattab, Zrig Eddakhlania (6072), Tunisia

${ }^{2}$ Center for Research in Information and Communication Sciences and Technology (CReSTIC), IUT, 9 Av Quebec, 10000 Troyes, France

\begin{abstract}
A novel non-linear power point tracking method of photovoltaic system (PV) based on synergetic control strategy is proposed. This technique uses a synergetic control strategy to achieve the maximum power point output without a chattering phenomenon. The PV system consists of a PV panel, DC-DC boost converter, MPPT controller and an output load. Synergetic control is easy to implement, has controllable dynamics towards the origin and gives a good maximum power operation under environmental changes (solar radiation and PV cell temperature). To show the robustness and validity of this approach a mathematical model is presented and simulated using Matlab/SIMULINK under different atmospheric conditions. Indeed, the simulation results showed the advantages of this new algorithm, especially the reduction of the chattering problem.
\end{abstract}

Keywords: PV system; Synergetic control; Maximum power point tracking; Boost converter; PV panel

\section{Introduction}

Nowadays, solar energy has great importance because of its sustainability and environmental friendly characteristic. The photovoltaic module represents the fundamental power conversion unit of PV system, the fact that the output characteristic depends on the solar radiation and the cell temperature [1]. In order to get the maximum of power from solar panels and enhance the PV system's efficiency, the selection of a maximum power point tracker (MPPT) algorithm is necessary [2].

A significant number of MPPT control systems have been developed for years to extract the maximum power that the photovoltaic module can provide [3]. Each MPPT has its own advantages and disadvantages. Due to their simplicity, perturbation and observation $(\mathrm{P} \& \mathrm{O})$ algorithm and incremental conductance (IC) method are the most widely used $[4,5]$. The P\&O algorithm consists of perturbing the PV output voltage and observing the output power to determine the peak power direction. The IC methods compare between the instantaneous and the incremental conductance to track MPP [6]. However, these methods have some disadvantages: $\mathrm{P} \& \mathrm{O}$ control fails to track the MPP during the rapid solar irradiation changes and IC method around the maximum power point [7].

To solve these problems many solutions have been reported in literature. To get better performance to the PV system, an adaptive perturbation step size has been proposed [8]. This method is effective but it is complex in implementation as it needs the operation point location. In addition, the implementation of this control is switched between adaptive duty cycle and fixed duty cycle control.

There are also other techniques such as fractional short circuit current method [9] and fractional open circuit voltage method [10]. However, these two methods have a weaker and less accurate performance.

In addition, a several number of intelligent methods have been adopted to estimate the voltage and the load current values such as fuzzy logic, artificial neural networks and genetic algorithms [1113]. Such methods are frequently complex and require considerable knowledge in control system design.

Recently, sliding mode control (SMC) is used in photovoltaic systems $[14,15]$. SMC is a non-linear control strategy which has several advantages such as robustness, good dynamical response and simplicity in its implementation. On the other hand, its major drawback is a chattering phenomenon. Hence, this phenomenon induces many undesirable oscillations in control signal [16]. Synergetic control (SC) as a solution is proposed in this paper to ensure stability of PV system with fast dynamic response. Synergetic control theory is introduced in ref. [17]. SC, like sliding mode control, is a non-linear control strategy. It allowed changing the system structure by switching from one set of continuous functions of state to another at any instant [18]. Synergetic control has the advantage of finite time convergence and tiny steady state error. In addition, it should achieve similar performance as SMC without chattering phenomenon [19]. A MPPT control strategy based on SC has been presented in ref. [20]. However this algorithm has the drawback such as parameter tuning difficulties and complexity. Therefore, the aim of this paper is to develop a novel SC scheme that is simple to implement and possesses an excellent steady state performance.

Inspired from the above work, this paper proposes a novel MPPT using synergetic approach for stand-alone photovoltaic system. The outline of the paper is as flows. The PV panel model is described in section II. Section III presents the mathematical model for a boost DCDC converter. In the following section, synergetic approach procedure is exposed and the proposed synergetic MPPT controller is given. Section $\mathrm{V}$ presents the simulation result and discussion. In the last section, conclusions are given.

\section{Photovoltaic Generator}

\section{How a PV cell working}

Photovoltaic cell is basically a $\mathrm{p}-\mathrm{n}$ junction which converts directly

*Corresponding author: Nadia Mars, SPEG, ENIG, Tunisia, Center for Research in Information and Communication Sciences and Technology (CReSTIC), IUT, 9 Av Quebec, 10000 Troyes, France, Tel: 0021694286002; E-mail: nedyamars@hotmail.fr

Received July 14, 2017; Accepted July 25, 2017; Published July 27, 2017

Citation: Mars N, Grouz F, Essounbouli N, Sbita L (2017) Synergetic MPPT Controller for Photovoltaic System. J Electr Electron Syst 6: 232. doi: 10.4172/23320796.1000232

Copyright: ( 2017 Mars N, et al. This is an open-access article distributed under the terms of the Creative Commons Attribution License, which permits unrestricted use, distribution, and reproduction in any medium, provided the original author and source are credited. 
Citation: Mars N, Grouz F, Essounbouli N, Sbita L (2017) Synergetic MPPT Controller for Photovoltaic System. J Electr Electron Syst 6: 232. doi: 10.4172/2332-0796.1000232

Page 2 of 7

sunlight to electricity. When the cell exposed to the sunlight, the cell photons are absorbed by the semiconductor atoms, freeing electrons from the negative layer. These electrons find their path through an external circuit toward the positive layer resulting an electric current $[21,22]$. Monocrystalline, polycrystalline and thin film technologies are the major families of PV cells. The absorption depends mainly on the cell surface, semiconductor or band gap, the temperature and the solar radiation [23]

\section{PV panel model}

To model the PV Panel, the scientific community offer several models. The single diode model is the most classical one described in literature [24]. The equivalent circuit (Figure 1) consists of current source to model the incident luminous flux, a diode for cell polarisation phenomena, a parallel resistance due to leakage current and a series resistance representing various contacts [6].

The general mathematical PV cell equation is given by the following equation [25]

$$
\mathrm{I}=\mathrm{I}_{\mathrm{ph}} \mathrm{N}_{\mathrm{p}}-\mathrm{I}_{\mathrm{d}}-\mathrm{I}_{\text {sh }}
$$

Where, $I_{p h}$ is a photo current, $I_{d}$ is a diode current and $I_{s h}$ a shunt current. The module photo-current evaluated as:

$$
\mathrm{I}_{\mathrm{ph}}=\mathrm{G}_{\mathrm{k}}\left[\mathrm{I}_{\mathrm{sc}}+\mathrm{k}_{\mathrm{I}}\left(\mathrm{T}_{\mathrm{op}}-\mathrm{T}_{\mathrm{ref}}\right)\right]
$$

The shunt current is described by the following equation:

$$
I_{s h}=\frac{V_{p v}+I_{p v} R_{s}}{R_{s h}}
$$

The dark current $\mathrm{I}_{\mathrm{d}}$ is calculated by the following equation:

$$
I_{d}=I_{s}\left[\exp \left(q \frac{V_{p v}+R_{S} I_{p v}}{N_{S} V_{t}}\right)-1\right]
$$

The reserved saturation current varies with temperature is described according to the following equation:

$$
I_{s}=I_{r s}\left(\frac{T_{o p}}{T_{r e f}}\right)^{3} e^{\left[\frac{q E g}{n k}\left(\frac{1}{T_{o p}}-\frac{1}{T_{r e f}}\right)\right]}
$$

Finally the output current can be expressed as:

$$
I=N_{p} I_{p h}-N_{p} I_{s}\left[\exp \left(\frac{q V_{p v}+R_{S} I_{p v}}{N_{S} V_{t}}\right)-1\right]-N_{p} \frac{V_{p v}+I_{p v} R_{S}}{R_{S h}}
$$

An ideal PV cell has very high equivalent shunt resistance and very low equivalent series resistance (Simplification $\mathrm{R}_{\mathrm{sh}} \gg>>\mathrm{R}_{\mathrm{s}}$ )

Equation (1) with $\mathrm{R}_{\mathrm{s}}=0$ and $\mathrm{R}_{\mathrm{sh}}=\infty$ becomes:

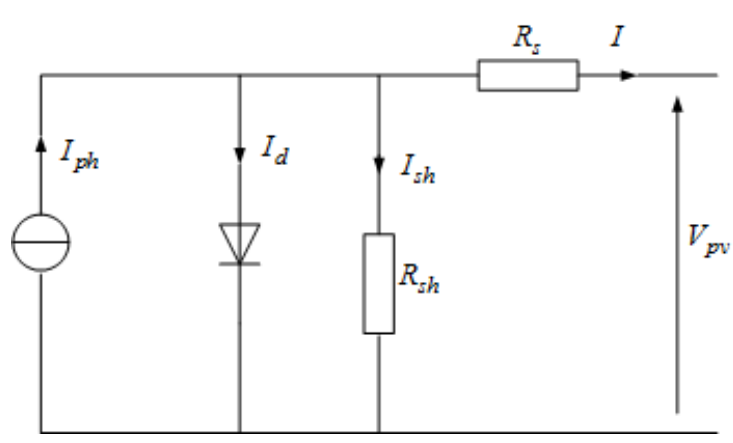

Figure 1: Equivalent circuit of solar cell.

$$
I=N_{p} I_{p h}-N_{p} I_{s}\left[\exp \left(\frac{A V_{p v}}{N_{S} n}\right)-1\right]
$$

\section{PV characteristics}

The PV panel specifications used for simulations are presented in Table 1.

Figure 2 shows the typical current versus voltage and power versus voltage curves for the photovoltaic module. Figures 3 and 4 show the I-V and P-V characteristics of PV module under different temperature levels (fixed irradiance). Figures 5 and 6 show the I-V and $\mathrm{P}-\mathrm{V}$ characteristics of $\mathrm{PV}$ module under different solar radiation levels (fixed temperature) [20].

It is clear that the PV module inherits nonlinear characteristics at its MPP. This MPP varies with temperature and irradiance. Hence, PV panel power increases with irradiance increasing or temperature decreasing. Therefore, in order to ensure that the photovoltaic system work at its MPP, a control algorithm is needed.

\begin{tabular}{|l|c|}
\hline Maximum power (Pmax) & $60 \mathrm{~W}$ \\
\hline Open-circuit voltage (Voc) & $21.1 \mathrm{~V}$ \\
\hline Short-circuit current (Isc) & $3.8 \mathrm{~A}$ \\
\hline Optimum operating voltage (Vmpp) & $17.1 \mathrm{~V}$ \\
\hline Optimum operating current (Impp) & $3.5 \mathrm{~A}$ \\
\hline
\end{tabular}

Table 1: Specifications of PV Panel.

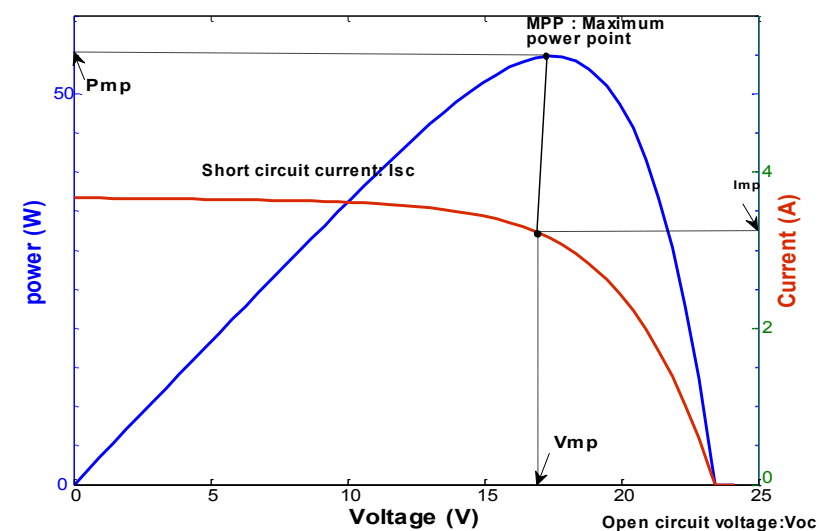

Figure 2: I-V and $P-V$ characteristic curves at a fixed irradiation $\left(G=1000 \mathrm{~W} / \mathrm{m}^{2}\right.$ and a fixed temperature $\left(T=25^{\circ} \mathrm{C}\right)$

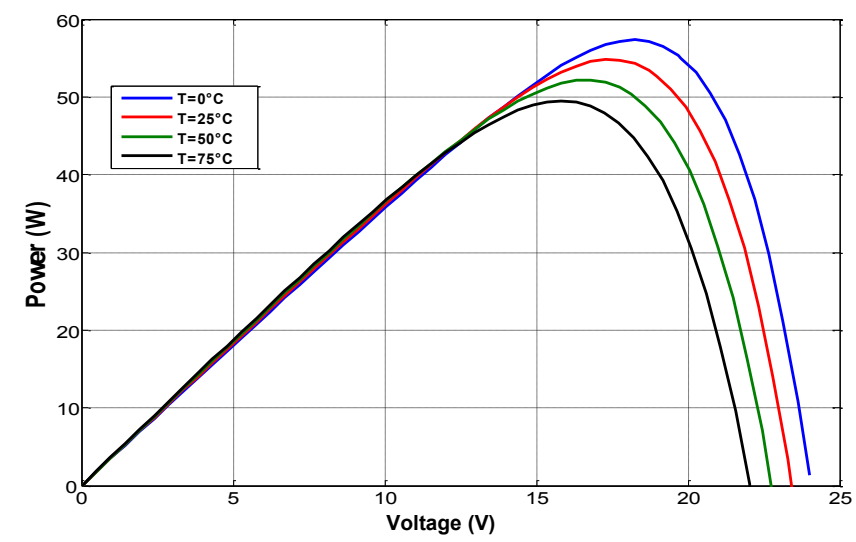

Figure 3: Power-Voltage curve in different temperature $\left(\mathrm{G}=1000 \mathrm{~W} / \mathrm{m}^{2}\right)$. 
Citation: Mars N, Grouz F, Essounbouli N, Sbita L (2017) Synergetic MPPT Controller for Photovoltaic System. J Electr Electron Syst 6: 232. doi: 10.4172/2332-0796.1000232

Page 3 of 7

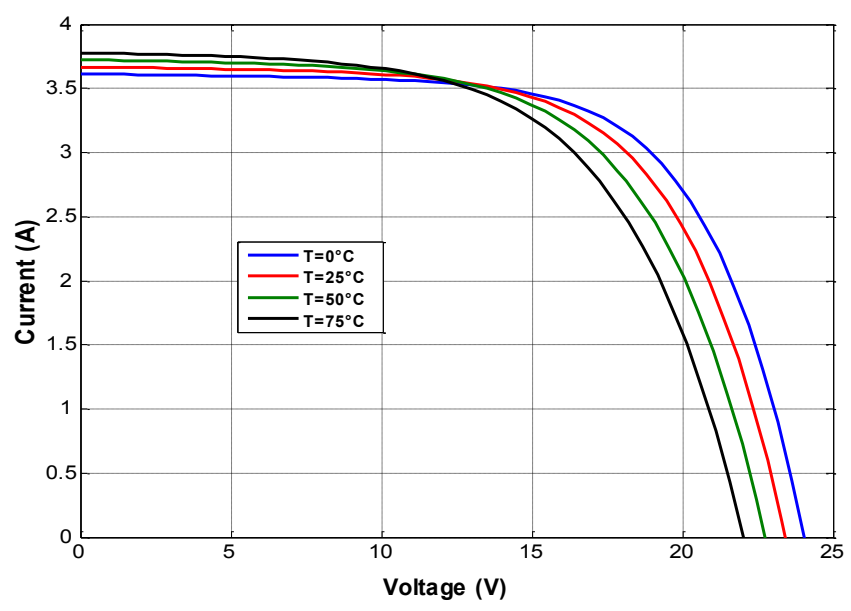

Figure 4: Current-Voltage curve in different temperature $\left(\mathrm{G}=1000 \mathrm{~W} / \mathrm{m}^{2}\right)$.

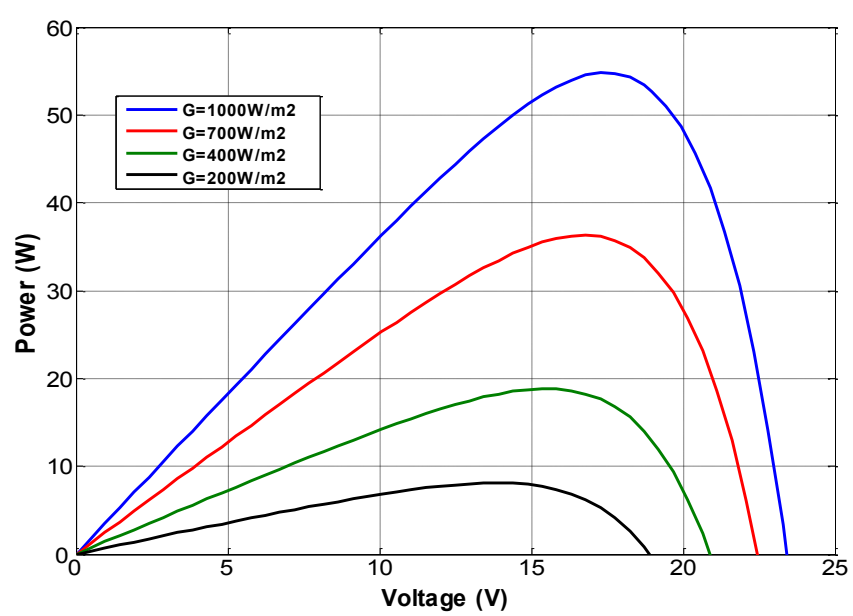

Figure 5: Power-Voltage curve in different irradiance $\left(\mathrm{T}=25^{\circ} \mathrm{C}\right)$.

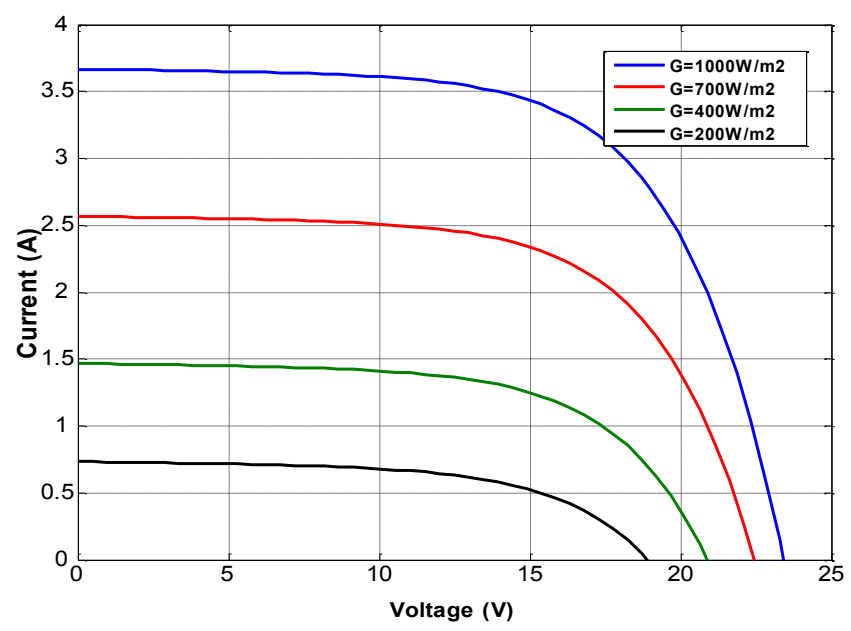

Figure 6: Current-Voltage curve in different irradiance.

\section{DC-DC Converter}

In order to extract the maximum power from the PV module, the DC-DC converter allows adaptation between the PV module and the load [3]. Figure 7 shows the circuit of the boost converter, whose output voltage $\left(\mathrm{V}_{0}\right)$ is more than or equal to the input voltage $\mathrm{V}_{\mathrm{pv}}(\mathrm{PV}$ generator voltage).

The switch $\mathrm{S}$ operates at a high frequency to produce a chopped output voltage [26]. The power flow is controlled by adjusting the ON and off of the switching. Hence, When $S=1$, the switch is $\mathrm{ON}$. The equations can be written as:

$$
\left\{\begin{array}{l}
\frac{d V_{p v}}{d t}=\frac{1}{C 1}\left(i_{p v}-i_{L}\right) \\
\frac{d I_{L}}{d t}=\frac{1}{L} V_{p v} \\
\frac{d V_{0}}{d t}=\frac{1}{C 2}\left(i_{L}-i_{0}\right) \frac{1}{C 2} i_{L}
\end{array}\right.
$$

When $S=0$, the switch is OFF the equation can be expressed in equation:

$$
\left\{\begin{array}{l}
\frac{d V_{p v}}{d t}=\frac{1}{C 1}\left(i_{p v}-i_{L}\right) \\
\frac{d I_{L}}{d t}=\frac{1}{L} V_{p v}-\frac{1}{L} V_{0} \\
\frac{d V_{0}}{d t}=\frac{1}{C 2}\left(i_{L}-i_{0}\right)
\end{array}\right.
$$

The boost converter can be used to drive a high voltage load from a low voltage PV module. The dynamic model of the used boost converter can be derived as:

$$
\left\{\begin{array}{l}
\frac{d V_{p v}}{d t}=\frac{1}{C 1}\left(i_{p v}-i_{L}\right) \\
\frac{d I_{L}}{d t}=\frac{1}{L} V_{p v}+\frac{1}{L}(S-1) V_{0} \\
\frac{d V_{0}}{d t}=\frac{1}{C 2}\left(i_{L}-i_{0}\right)-\frac{1}{C 2} S i_{L}
\end{array}\right.
$$

If we set $\mathrm{x}=\left[\begin{array}{lll}x_{1} & x_{2} & x_{3}\end{array}\right]^{\mathrm{Tr}}=\left[V_{p v} i_{L} V_{0}\right]^{\mathrm{Tr}}$

With Tr matrix transpose, the above expression can be written as: $\dot{x}=\frac{d x}{d t}=f(x, t)+g(x, t) S$

Where,

$$
x=\left[\begin{array}{l}
V_{p v} \\
i_{L} \\
V_{0}
\end{array}\right] ; f(x)=\left[\begin{array}{l}
\frac{1}{C 1}\left(i_{p}-i_{L}\right) \\
\frac{1}{L}\left(V_{p v}-V_{0}\right) \\
\frac{1}{C 2}\left(i_{L}-i_{0}\right)
\end{array}\right] ; g(x)=\left[\begin{array}{l}
0 \\
\frac{1}{L} V_{0} \\
-\frac{1}{C 2} i_{L}
\end{array}\right]
$$

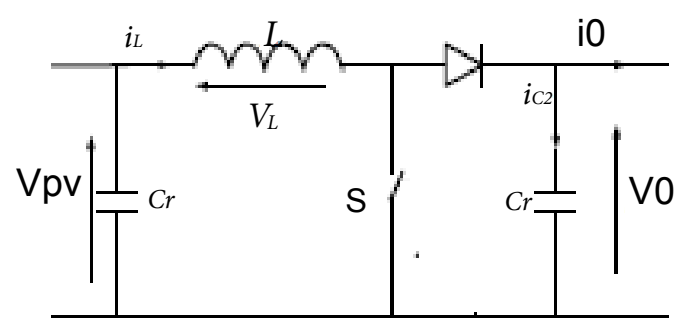

Figure 7: Diagram of boost converter. 


\section{Synergetic MPPT Controller}

\section{Synergetic control procedure}

The general synergetic control procedure is reviewed in this section. Synergetic control theory is a nonlinear approach, it uses a non-linear model of the power system to overcome the above mentioned problems of the linear controls [27]. The nonlinear differential equation of the system can be described by the following form $[28,29]$.

$$
\dot{x}=\frac{d x}{d t}=f(x, s, t)
$$

Where $\mathrm{x}=\left(x_{1}, x_{2}, \ldots, x_{n}\right)$ is the state variable vector of size $\mathrm{n}, \mathrm{s}=\left(s_{1}, s_{2}, \ldots, s_{m}\right)$ is the control input of size $m=1$ and $t$ is time.

The SC approach is based on a particular choice of the macro variable. Therefore, we started by defining a nonlinear macro-variable as follows:

$$
\Psi=\Psi(x, t)
$$

The controller objective is to force the system to operate the manifold $(\Psi=0)$. However, using the same procedure as in the synergetic approach $[30,31]$. The macro-variable can be a simple linear combination of the state variables. Hence, the designer can select the characteristics of this macro-variable according to the control specifications such as the settling time and the control objective. The desired dynamic evolution of the macro-variable is:

$$
T \dot{\Psi}+\Psi=0, T \succ 0
$$

Where $\mathrm{T}$ is a specific designer chosen that determines the rate of convergence speed to the manifold specified by the macro-variable. Taking into account the chain rule of differentiation that is given by:

$$
\dot{\Psi}=\frac{d \Psi}{d x} \dot{x}
$$

Combining 12, 14 and 15

$$
T \frac{d \Psi}{d x} f(x, s, t)+\Psi=0
$$

Finally upon solving equation 16 , the control law can be described as flow:

$$
S=\delta[x, t, \Psi(x, t), T]
$$

As can be seen, the control output $S$ depends not only on the system state variables but also on the time constant $\mathrm{T}$ and the macro variable $\Psi$ as well giving the designer latitude to choose the characteristics of the controller by selecting a suitable macro-variable and a constant time T. By suitable selection of macro-variable, the designer can obtain many interesting characteristics such as:

- Stability

- Noise suppression

- Parameters ffinsensffitffivffity.

The procedure summarized here can be performed by hand for simple systems, such as the DC-DC boost converter used for this study, which has a small number of state variables.

\section{Synergetic MPPT controller}

Maximum power point tracking is an essential stage of a photovoltaic system for tracking the maximum power. The system studied in this paper is a stand-alone PV system. As shown in Figure 8,

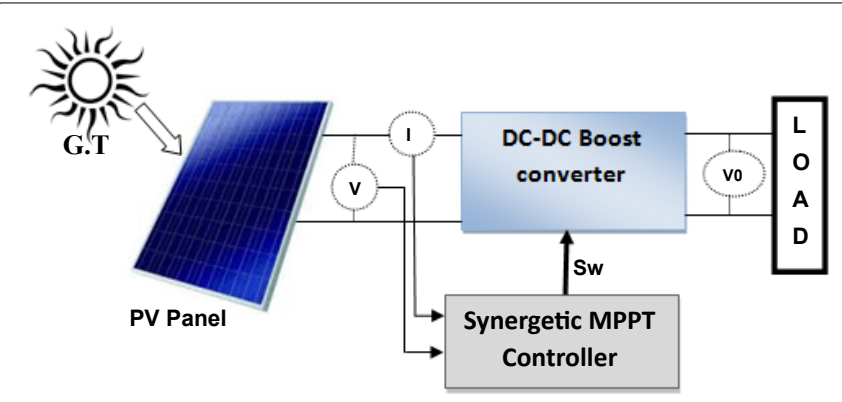

Figure 8: Block diagram of PV system with synergetic controller.

it consists of a PV panel, a DC-DC converter, a load and a synergetic controller.

Like all other MPPT, the modelling of the synergetic MPPT controller is based on the output power of the cell which is $\mathrm{P}=\mathrm{V}^{\star} \mathrm{I}$. The optimisation of the output power is achieved as shown in Figure 2, by selecting the manifold as:

$$
\frac{\partial P}{\partial V}=0
$$

Hence, the manifold is defined as:

$$
\Psi=\frac{\partial P}{\partial V}=V \frac{\partial I}{\partial V}+I
$$

In studied DC-DC boost converter, there are two states: the output voltage (x1) and the inductor current (x2). As $\Psi$ is function of $x 1$ only, hence the chain rule of differentiation becomes:

$$
\dot{\Psi}=\frac{d \Psi}{d x} \dot{V}=2\left[\frac{\partial I}{\partial V}+\frac{\partial^{2} I}{\partial V^{2}} V\right] \dot{V}
$$

Then the desired dynamic evolution of the macro-variable can be expressed:

$$
T \dot{\Psi}+\Psi=0 ; T \geq 0
$$

So,

$$
\begin{aligned}
& T\left[2 \frac{\partial I}{\partial V}+\frac{\partial^{2} I}{\partial V^{2}} V\right] \dot{V}+V \frac{\partial I}{\partial V}+I=0 \\
& d=1-\frac{V}{V_{0}}=\frac{V \frac{\partial I}{\partial V}+I}{\frac{V_{0}}{L}\left[2 \frac{\partial I}{\partial V}+\frac{\partial^{2} I}{\partial V^{2}} V\right]}
\end{aligned}
$$

\section{Stability proof}

Based on Lyapunov function the macro-variable requires that:

$$
\dot{V}=\frac{1}{2} \Psi^{2} \succ 0 ; \dot{V}=\Psi=\frac{d \Psi}{d x} \prec 0 ; \Psi \dot{\Psi} \prec 0
$$

\section{Results and Discussion}

The PV model system has been implemented in Matlab/Simulink shown in Figure 9, which includes the PV array, the DC-DC boost converter with an MPPT controller connected to a load. The PV modules specifications' are shown in Table 1.The converter circuit topology is designed to be compatible with given load to achieve the maximum power transfer from the solar panel. The MPPT system specification' used in the simulation is shown in Table 2. 


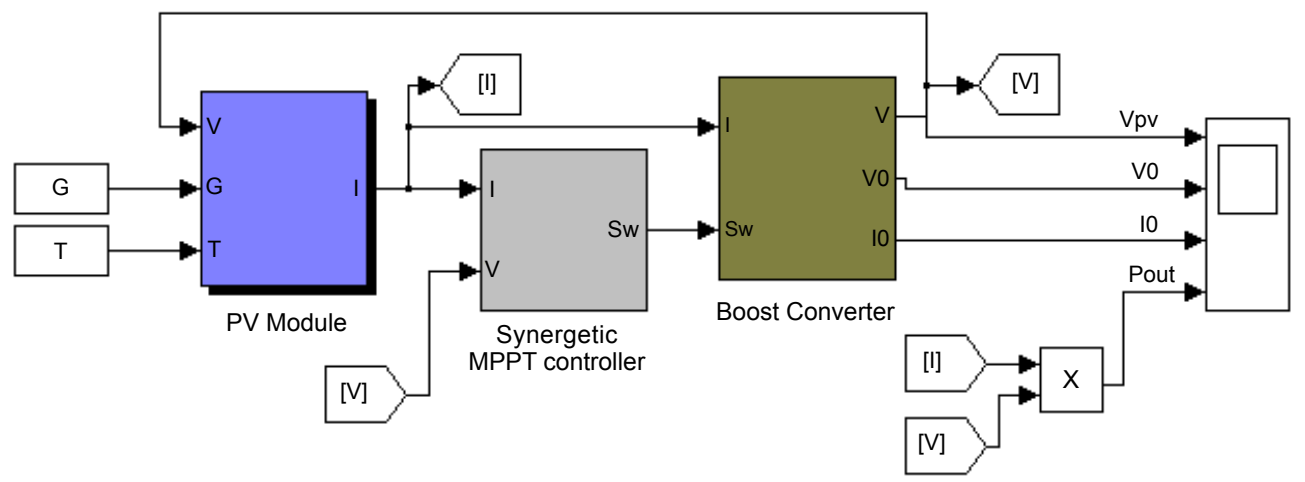

Figure 9: Simulation diagram of the stand-alone PV system.

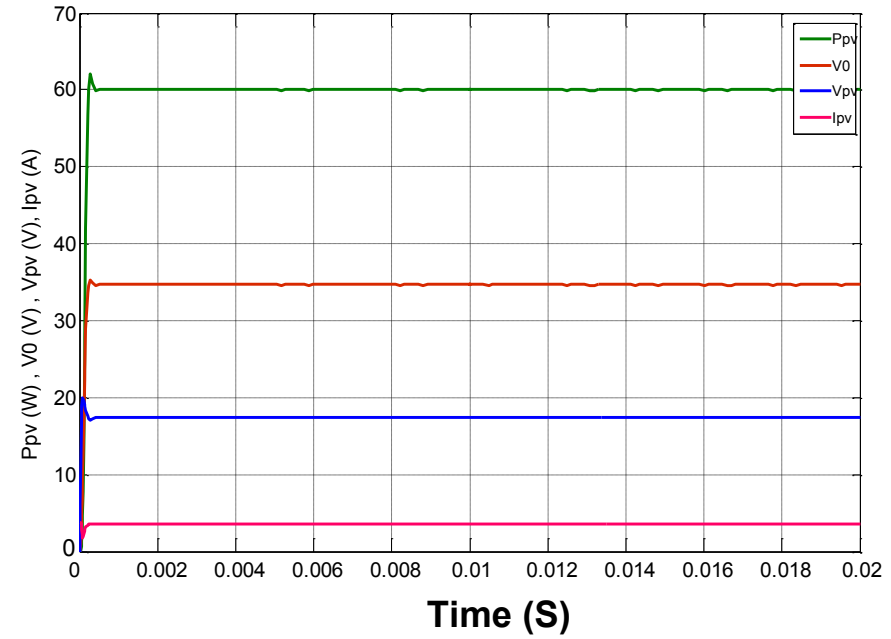

(a)

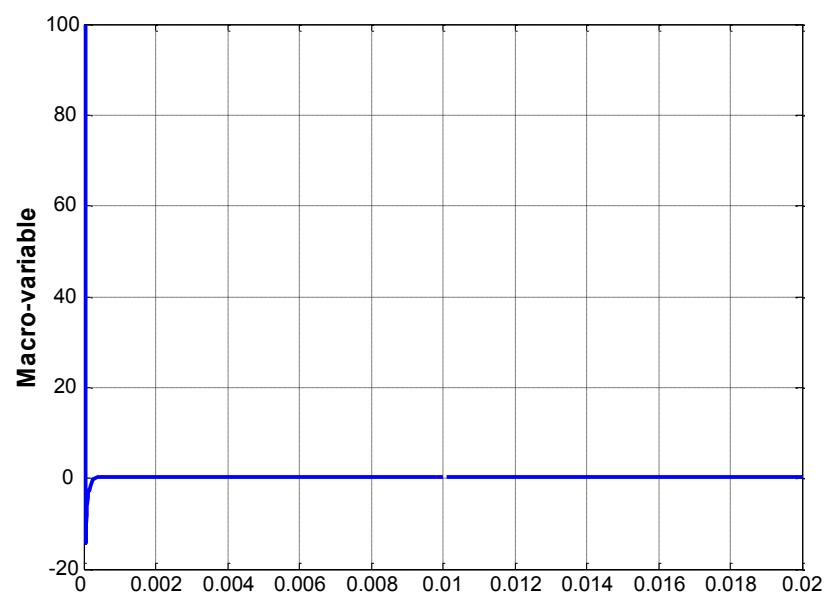

Time (S)

(b)

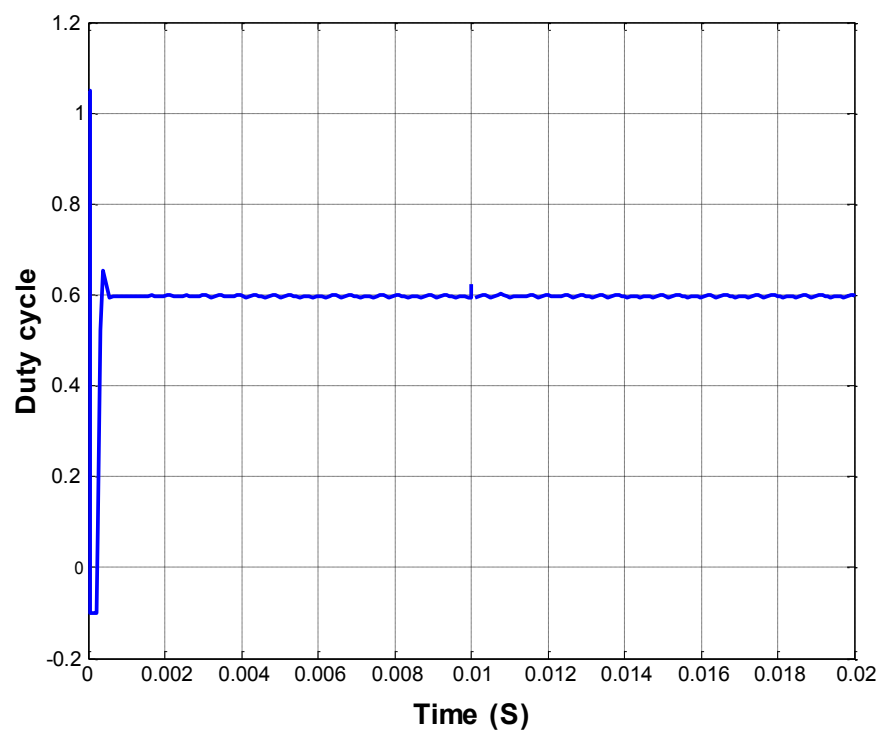

(c)

Figure 10: Simulation with standard condition (a) Ppv, V0, Vpv and Ipv, (b) Duty Cycle and (c) macro variable. 
Citation: Mars N, Grouz F, Essounbouli N, Sbita L (2017) Synergetic MPPT Controller for Photovoltaic System. J Electr Electron Syst 6: 232. doi: 10.4172/2332-0796.1000232

To evaluate the effectiveness of proposed MPPT, We consider the PV cell with irradiance is $1000 \mathrm{~W} / \mathrm{m}^{2}$ and temperature is $25^{\circ} \mathrm{C}$. The simulation results of the output power, the PV panel voltage, the output voltage and the PV panel current are shown in Figures10a-10c show the duty cycle and the macro-variable.

The photovoltaic system is dependent on the temperature and irradiation conditions and the power will be maximum for along the variations of temperature and irradiation in the PV panel which is giving to input to DC-DC converter. Therefore, we will evaluate the robustness of the proposed MPPT according to temperature and irradiance variation. In each figure, two different values of temperature

\begin{tabular}{|c|c|}
\hline $\mathbf{L}$ & $480(\mathrm{mH})$ \\
\hline $\mathbf{R}$ & $5(\Omega)$ \\
\hline $\mathbf{K}$ & $1.38 \mathrm{e}-23(\mathrm{~J} / \mathrm{K})$ \\
\hline $\mathbf{Q}$ & $1.6 \mathrm{e}-19(\mathrm{C})$ \\
\hline $\mathbf{R s}$ & $0.18(\Omega)$ \\
\hline $\mathbf{R p}$ & $360(\Omega)$ \\
\hline $\mathbf{N}$ & 36 \\
\hline $\mathbf{T}$ & 0.003 \\
\hline
\end{tabular}

Table 2: System specifications

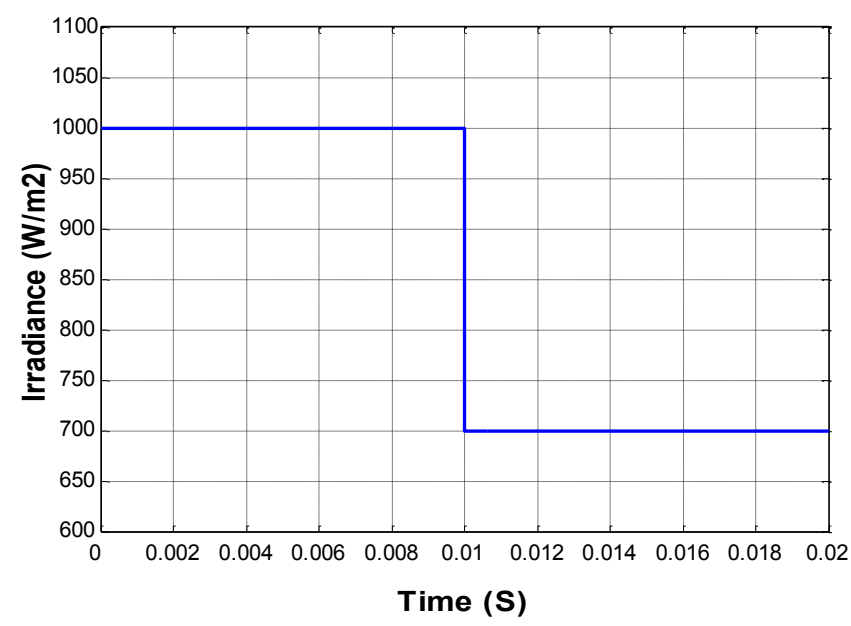

Figure 11: Solar irradiance variation.

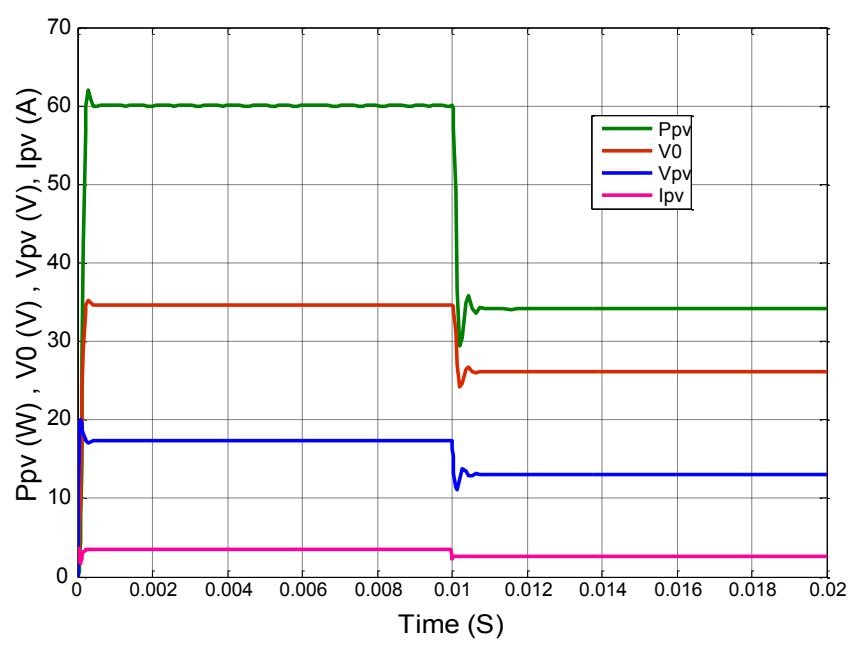

Figure 12: Simulation with step irradiance change $\left(1000 \mathrm{~W} / \mathrm{m}^{2}, \mathrm{~T}=25^{\circ} \mathrm{C}\right)$.

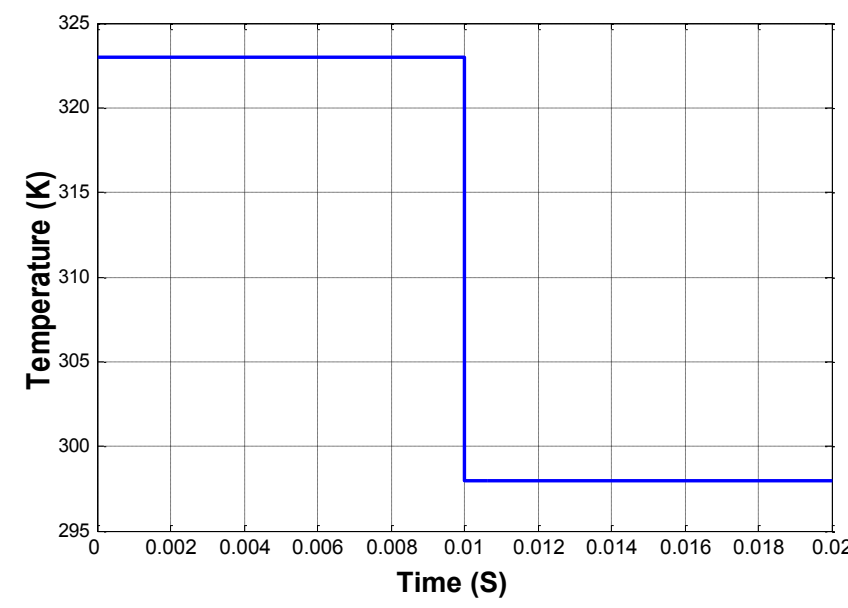

Figure 13: Temperature variation.

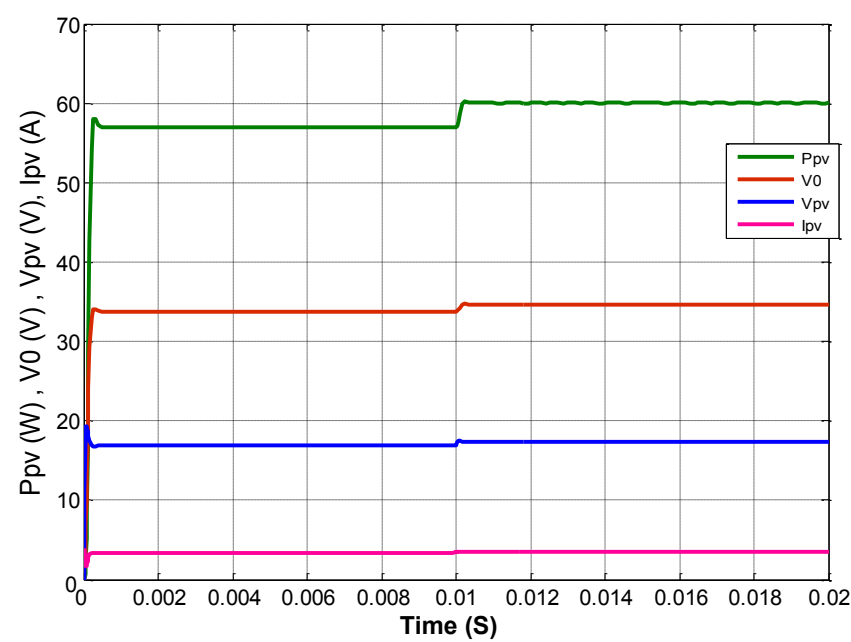

Figure 14: Simulation with step irradiance change $\left(1000 \mathrm{~W} / \mathrm{m}^{2}, \mathrm{~T}=25^{\circ} \mathrm{C}\right)$.

or irradiance are presented in order to show the robustness (Figures 11-14).

All the obtained results show that the use of synergetic MPPT controller is effective. The SC ensures very fast convergence to the MPP and there are no oscillations around the MPP. Moreover it provides a high robustness with the variation of the external conditions (temperature and solar irradiance).

\section{Conclusion}

In this paper, a whole PV system with optimal control strategy has been presented. The Synergetic control is formulated and applied to the PV system. This system consists of a solar panel, DC-DC boost converter, synergetic MPPT controller and an output load. The effectiveness and the robustness of the proposed MPPT are proven by simulation results.

It is proved using Simulation Matlab/Simulink that the designed SC showed good results as it successfully and precisely tracked the MPP with a significantly higher efficiency. Hence, synergetic control eliminates chattering effects and robust to abrupt change of solar radiation and temperature. 
In further work, these results will be experimentally validated.

\section{References}

1. Kachhiya K, Lokhande M, Patel M (2011) Matlab/simulink model of solar PV module and MPPT algorithm. National Conference on Recent Trends in Engineering and Technology.

2. Rao GJ, Mangal DK, Shrivastava SK, Baig MG (2016) Modeling and Simulation of Incremental Conductance Maximum Power Point Tracking (MPPT) Algorithm for Solar PV Array Using Boost Converter. IJSRSET.

3. Atik L, Petit P, Sawicki JP, Ternifi ZT, Bachir G, et al. (2016) Comparison of four MPPT techniques for PV systems. AIP Conference Proceedings 1758(1): 10.1063/1.4959443.

4. Zegaoui A, Aillerie M, Petit P, Sawick JP, Charles JP, et al. (2011) Dynamic behaviour of $\mathrm{PV}$ generator trackers under irradiation and temperature changes. Solar Energy 85: 2953-2964.

5. Zegaoui A, Aillerie M, Petit P, Sawick JP, Jaafar A, et al. (2011) Comparison of Two Common Maximum Power Point Trackers by Simulating of PV Generators. Energy Procedia 6: 678-687.

6. Belkaid A, Gaubert JP, Gherbi A (2016) An Improved Sliding Mode Control for Maximum Power Point Tracking in Photovoltaic Systems. CEAI 18: 86-94.

7. Gomes de Brito MA, Galotto L, Sampaio LP, Melo GA, Canesin CA, et al (2013) Evaluation of the Main MPPT Techniques for Photovoltaic Applications. IEEE Transactions on Industrial Electronics 60: 1156-1167.

8. Jiang Y, Abu Qahouq JA, Haskew TA (2013) Adaptive Step Size with Adaptive-Perturbation-Frequency Digital MPPT Controller for a Single-Sensor Photovoltaic Solar System. IEEE Transactions on Power Electronics 28: 31953205.

9. Kollimalla SK, Mishra MK (2013) A new adaptive P\&O MPPT algorithm based on FSCC method for photovoltaic system. International Conference on Circuits Power and Computing Technologies (ICCPCT), pp: 20-21.

10. Murtaza AF, Sher HA, Chiaberge M, Boero D, Giuseppe MD, et al. (2013) A novel hybrid MPPT technique for solar PV applications using perturb \& observe and Fractional Open Circuit Voltage techniques. 15th International Conference Mechatronika.

11. Esram T, Chapman PL (2007) Comparison of Photovoltaic Array Maximum Power Point Tracking Techniques. IEEE Transactions on Energy Conversion 22: 439-449.

12. Reisia AR, Moradib MH, Jamasb S (2013) Classification and comparison of maximum power point tracking techniques for photovoltaic system. Renewable and Sustainable Energy Reviews 19: 433-443.

13. Subudhi B, Pradhan R (2013) A Comparative Study on Maximum Power Poin Tracking Techniques for Photovoltaic Power Systems. IEEE Transactions on Sustainable Energy 4: 89-98.

14. Fan L, YU Y (2011) Adaptive Non-singular Terminal Sliding Mode Control for DC-DC Converters. Advances in Electrical and Computer Engineering 11: 119-122.

15. Romdhane NMB, Damak T (2011) Adaptive Terminal Sliding Mode Control for
Rigid Robotic Manipulators. International Journal of Automation and Computing 8: $215-220$.

16. Rezkallah M, Sharma SK, Chandra A, Singh B, Rousse DR (2017) Lyapunov Function and Sliding Mode Control Approach for the Solar-PV Grid Interface System. IEEE Transactions on Industrial Electronics 64: 785-795.

17. Kolesnikov AA (2000) Modern applied control theory: Synergetic Approach in Control Theory. TRTU, Moscow, Taganrog, pp: 4477-4479.

18. Utkin VI (1977) Variable structure systems with sliding mode. IEEE Transactions on Automatic Control 22: 212-222.

19. Abderrezek H, Harmas MN (2016) Comparison study between the terminal sliding mode control and the terminal synergetic control using PSO for DC-DC converter. 4th International Conference on Electrical Engineering (ICEE).

20. Attoui H, Khaber F, Melhaoui M, Kassmi K, Essounbouli N (2016) Development and experimentation of a new MPPT synergetic control for photovoltaic systems. Journal of Optoelectronics and Advanced Materials 18: 165-173.

21. Salmi T, Bouzguenda M, Gastli A, Masmoudi A (2012) MATLAB/Simulink Based Modelling of Solar Photovoltaic Cell. International Journal of Renewable Energy Research- IJRER.

22. Pandiarajan N, Muthu R (2011) Mathematical modelling of photovoltaic module with Simulink. 1st International Conference on Electrical Energy Systems.

23. Kumari JS, Babu CS (2012) Mathematical Modeling and Simulation of Photovoltaic Cell using Matlab-Simulink Environment. International Journal of Electrical and Computer Engineering (IJECE) 2: 26-34

24. Mehimmedetsi B, Chenni R (2016) Modelling of DC PV system with MPPT. 3rd International Renewable and Sustainable Energy Conference (IRSEC).

25. Ramos-Hernanz JA, Campayo JJ, Larranaga J, Zulueta E, Barambones $\mathrm{O}$ et al. (2012) Two photovoltaic cell simulation models in matlab/Simulink International Journal on Technical and Physical Problems of Engineering (IJTPE) 4: 45-51.

26. Bendiba B, Krim F, Belmilia H, Almia MF, Bouloumaa S (2014) Advanced Fuzzy MPPT Controller for a Stand-alone PV System. Energy Procedia, pp: 383-392.

27. Jiang $Z$ (2007) Design of power system stabilizers using synergetic contro theory. IEEE Power Engineering Society General Meeting.

28. Laribi M, Aït Cheikh MS, Larbès C, Barazane L (2010) Application de la commande synergetique au contrôle de vitesse d'une machine asynchrone. Revue des Energies Renouvelables 13: 485-496.

29. Santi E, Monti A, Li D, Proddutur K, Dougal RA (2004) Synergetic Control fo Power Electronics Applications: A Comparison with the Sliding Mode Approach. Journal of Circuits, Systems and Computers.

30. Santi E, Monti A, Li D, Proddutur K, Dougal R (2003) Synergetic control fo dc-dc boost converter implementation option. IEEE Transactions on industry applications 39: 1803-1813.

31. Bezuglov A, Kolesnikov A, Kondratiev I, Vargas J (2005) Synergetic Contro Theory Approach For Solving Systems Of Nonlinear Equations. World MultiConference, Systemics Cybernetics and Informatics. 